\title{
PELATIHAN BAHASA INGGRIS PARIWISATA PADA PARA PELAKU USAHA WISATA RELIGI BUKIT KASIH KANONANG KAWANGKOAN, MINAHASA, SULAWESI UTARA
}

\author{
Mister Gidion Maru \\ Fakultas Bahasa dan Seni, Universitas Negeri Manado \\ mrgidionmaru@unima.ac.id
}

\begin{abstract}
Abstrak
Salah satu bidang usaha yang secara vital menuntut penguasaan Bahasa Inggris yang baik adalah usaha kepariwisataan. Pemberian pelatihan bahasa Inggris bagi para pelaku usaha wisata dipandang perlu dan penting untuk dilaksanakan. Dalam kaitan itu serta melihat adanya potensi wisata di Bukit Kasih desa Kanonang yang terus berkembang dan berpeluang untuk terus dibanjiri pengunjung, maka tidak dapat diabaikan lagi perlunya pelaksanaan pemberian pelatihan bahasa Inggris bagi para pelaku wisata disana mulai dari tukang parkir sampai para pemandu yang menghabiskan waktu mereka setiap hari dilokasi wisata tersebut. Dengan metode demonstrasi dan role play, kegiatan pelatihan menghasikan antaralain adanya tanggapan yang baik dari para pelaku usaha wisata dibuktikan dengan kehadiran dan partisipasi dalam kegiatan pelatihan, terbentuknya pengenalan akan kata-kata Bahasa Inggris yang dapat digunakan dalam kegiatan usaha wisata secara umum dan di Bukit Kasih Kanonang secara khusus, munculnya minat untuk lebih melatih diri atau mengikuti pelatihan terkait cara menyapa dan memandu pengunjung khususnya wisatawan asing sebagai upaya untuk meningkatkan pendapatan, dan bertambahnya wawasan kebahasaan khususnya penggunaan bahasa Inggris untuk tujuan peningkatan kualitas layanan bagi wisatawan asing yang berdampak pada peningkatan potensi arus dan kunjungan wisata ke kabupaten Minahasa dan khususnya Bukit Kasih Kanonang.
\end{abstract}

Kata Kunci: Usaha wisata religi, Bahasa Inggris, pariwisata, Bukit Kasih Kanonang.

\section{PENDAHULUAN}

Salah satu bidang usaha yang secara vital menuntut penguasaan Bahasa Inggris yang baik adalah usaha kepariwisataan. Usaha wisata yang tentunya mengandalkan kunjungan dari wisatawan tak dapat dipungkiri mendorong penguasaan bahasa Inggris sebagai kemampuan yang harus dimiliki oleh para pelaku dibidang tersebut. Kenyamanan pengunjung terutama wisatawan mancanegara jelas menuntut penggunaan bahasa Inggris sebagai media komunikasi global. Objek wisata yang menarik dan indah ataupun syarat makna sosio-historis dan kultural tidak akan dapat dinikmati secara utuh tanpa penjelasan dan deskripsi yang akurat kepada para pengunjung. Dengan adanya penggunaan bahasa Inggris yang baik maka tantangan tersebut dapat dijembatani dan dijawab. Lebih jauh lagi, manfaat ekonomis yang akan dicapai lewat usaha wisata itu dapat pula didapatkan. Dengan kata lain komunikasi yang baik dan nyaman antar pengunjung dan pengelola wisata akan memberi potensi pemasukan bagi kelanjutan usaha wisata tersebut sekaligus bagi para pelaku yang ambil bagian didalamnya.

Dengan pemikiran tersebut, maka pemberian pelatihan bahasa Inggris bagi 
para pelaku usaha wisata dipandang perlu dan penting untuk dilaksanakan. Dalam kaitan itu serta melihat adanya potensi wisata di Bukit Kasih desa Kanonang yang terus berkembang dan berpeluang untuk terus dibanjiri pengunjung, maka tidak dapat diabaikan lagi perlunya pelaksanaan pemberian pelatihan bahasa Inggris bagi para pelaku wisata disana mulai dari tukang parkir sampai para pemandu yang menghabiskan waktu mereka setiap hari dilokasi wisata tersebut. Penguasaan bahasa Inggris khususnya berhubungan dengan kegiatan pariwisata harus segera dilaksanakan tidak hanya untuk kelangsungan pengembangan lokasi wisata tetapi juga krusial untuk peningkatan pendapatan para pelaku wisata didalamnya. Dengan kata lain, pelatihan bahasa Inggris akan membekali para pelaku wisata dengan kemampuan komunikatif dengan pengunjung khususnya dari mancanegara yang akan berdampak pada keberhasilan pengembangan lokasi wisata Bukit Kasih Kanonang itu sendiri dan lebih khusus pada peningkatan pendapatan para pelaku usaha wisata di tempat tersebut.

Terkait dengan tantangan tersebut, kegiatan pengabdian berupa pelatihan ini bertujuan antaralain memberikan pengetahuan dan keterampilan komunikasi kepada para pelaku usaha wisata di Buki Kasih Kanonang, memberikan ketrampilan berbahasa Inggris sebagai modal untuk menghadapi masuknya wisatawan mancanegara dan membekali para pelaku usaha wisata dengan penguasaan bahasa Inggris pariwi174 sata untuk mendorong peningkatan pendapatan. Dengan demikian, adanya pengetahuan dan keterampilan seperti yang telah diuraikan tersebut, maka diharapkan para pelaku usaha wisata dapat memberi signifikansi dalam hal memiliki pengetahuan dan keterampilan komunikasi yang dapat dipakai untuk menghadapi arus kunjungan wisatawan mancanegara dan menguasai bahasa Inggris khususnya yang terkait dengan ungkapan-ungkapan seputar pariwisata sehingga mampu memberi kenyamanan bagi para pengunjung yang berbahasa Inggris. Oleh karena itu, khalayak sasaran pengabdian masyarakat ini tentu saja adalah para pelaku usaha wisata di Bukit Kasih desa Kanonang. Khalayak sasaran diutamakan para pelaku wisata yang belum mengikuti program pelatihan.

\section{METODE PELAKSANAAN}

Kegiatan pelatihan ini mengunakan beberapa metode dalam pelaksanaannya yakni Metode ceramah, Metode role play dan Metode demonstrasi. Sedangkan keberhasilan kegiatan pengabdian ini dapat dilihat dengan upaya evaluasi yang evaluasi dilakukan pada akhir kegiatan pelatihan dengan mempertimbangkan aspek-aspek sebagai berikut;

1. Kriteria evaluasi:

a. Bila mencapai di atas $75 \%$ dari tujuan yang ditetapkan, maka tujuan dinyatakan berhasil.

b. Bila mencapai antara 50\% sampai dengan $74 \%$ dari tujuan yang 
ditetapkan, maka tujuan dinyatakan kurang berhasil

c. Bila hanya mencapai 49 ke bawah dari tujuan yang ditetapkan, maka tujuan dinyatakan tidak berhasil.

2. Indikator yang digunakan dalam evaluasi adalah perubahan pengetahuan, keterampilan pelaku wisata dan nilai psikologis yang berhubungan dengan:

a. Kesadaran para pelaku usaha wisata tentang pentingnya komunikasi yang sesuai dengan tantangan global

b. Adanya penguasaan ketrampilan berbahasa Inggris parisiwata yang dapat dipahami.

c. Penguasaan berbahasa Inggris yang dapat dipakai untuk menyambut kunjungan wisatawan mancanegara.

d. Motivasi dalam berpartisipasi aktif untuk pengembangan pengetahuan dan keterampilan berbahasa yang telah dimiliki.

3. Tolak ukur yang digunakan dalam pelaksanaan evaluasi adalah seperti apa yang telah dirumuskan pada tujuan pengabdian pada masyarakat yang akan dilakukan.

\section{HASIL DAN PEMBAHASAN}

Kemampuan bahasa Inggris untuk tujuan pariwisata merupakan bagian dari pembelajaran bahasa Inggris untuk tujuan khusus (English for Specific Purpose/ESP). Hal itu terkait dengan proposisi bahwa pada dasarnya pembelajaran bahasa Inggris akan bertujuan memampukan pembelajarnya untuk dapat menggunakan bahasa tersebut secara lisan maupun tertulis dengan baik dan benar. Namun demikian, kekhususan tiap bidang ilmu atau aspek kehidupan telah melahirkan cara pengungkapan dan perbendaharaan kata yang makin beragam sesuai dengan karakter bidang tersebut. Oleh karena itu, Bahasa Inggris untuk pariwisata dapat dipahami sebagai bahasa Inggris yang berhubungan dengan ungkapan-ungkapan dan kata-kata yang lazim dipakai dalam proses komunikasi dikalangan pelaku usaha atau industri pariwisata. Kemampuan bahasa Inggris pariwisata sudah semestinya dikuasai oleh para pihak yang bergelut di usaha pariwisata mulai dari pengelola sampai pedagang asongan. Penguasaan kemampuan bahasa ini diyakini akan mendorong kemampuaan komunikatif yang berdampak pada kenyamanan konsumen atau pengunjung dalam menikmati destinasi yang ditawarkan sekaligus pada kemampuan untuk memasarkan atau mempromosikan objek yang dimaksud dan tentunya akan bermanfaat.

Pengabdian kepada masyarakat ini dilaksanakan bagi pelaku usaha wisata di lokasi wisata religi Bukit Kasih Kanonang yang merupakan salah satu pilar kegiatan ekonomi sekaligus sebagai upaya peningkatan pendapatan masyarakat. Kegiatan pengabdian berupa pelatihan bahasa Inggris ini diharapkan dapat membekali dan mendorong peningkatan 
jasa dan layanan bagi para pengunjung. Hal tersebut bermakna peningkatan potensi pendapatan sebagai dampak dari peningkatan kualitas layanan khususnya bagi wisatawan mancanegara. Dengan kata lain, kegiatan pengabdian berupa pelatihan bahasa Inggris Pariwisata dapat membuka ruang untuk peningkatan kualitas layanan, yang selanjutnya meningkatkan potensi arus wisatawan. Kegiatan ini meliputi pemberian materi, dengan waktu pelaksanaan yang ditentukan.

\section{Materi Pelatihan}

Materi yang diberikan dalam kegiatan pengabdian ini adalah pengenalan akan perbendaharaan kata yang terkait dengan kepariwisataan, dan cara-cara menyapa dan memandu wisatawan asing. Berikut contoh-contoh materi yang digunakan.

Expression for tour guide https://www.englishclub.com/englishfor-work/tour-guide-interest.htm Silence can be uncomfortable during a tour. While you can't talk the whole time, you should try to know as much about the history, scenery, and culture (in English) for the places where you are giving tours so that you can keep the tourists interested. If you ever run out of something to say, you can always point out something such as a landmark or a type of tree or flower. Here are some different ways you can point out interest points during the tour.
Tour Guide

- In front of you is...

- On your right/left you will see...

- Up ahead...

- On your left you will see...

- As we turn the corner here, you will see...

- In the distance...

- If you look up you will notice...

- Off to the north...

- Look to the east...

- To your west...

- In a few minutes we'll be passing...

- We are now coming up to...

- $\quad$ As you will see...

- You may have noticed...

- Take a good look at...

- I'd like to point out...

- Keep your eyes open for...

Tourist Questions

- Is that the...you were talking about?

- Are we going to pass the...?

- Are we going to see any...?

- Is it on the right or the left?

- I don't see it. Can you point it out again?

- Did I miss it?

- Will we see it on the way back?

\section{Metode dan Peserta Pelatihan}

Pelatihan ini dilakukan dengan menggunakan metode ceramah/demonstrasi disertai dengan role play. Pelatihan ini diikuti oleh para pelaku usaha wisata di Bukit Kasih desa Kanonang khususnya yang 
sering berinteraksi dengan wisatawan asing.

\section{Jadwal Waktu Pelaksanaan}

Pelaksanaan kegiatan diawali dengan sosialisasi dan persiapan di tempat pelatihan. Pelaksanaan pelatihan dilaksanakan selama 2 hari mulai tanggal 2 sampai dengan 3 Agustus 2016.

Kegiatan pengabdian dapat dikatakan berhasil menarik minat dan kesadaran masyarakat akan pentingnya penguasaan bahasa Inggris khususnya yang dapat digunakan dalam interaksi dengan wisatawan asing yang kehadirannya makin meningkat di Wisata Religi Bukit Kasih di Kanonang. Walaupun belum semua pelaku usaha wisata yang mengambil bagian dalam kegiatan pelatihan ini, antusiasme yang terpancar lewat partisipasi para pelaku wisata baik berupa pertanyaan maupun komentar menunjukan bahwa pelatihan semacam ini tampaknya menjawab kerinduan para pelaku wisata tersebut untuk dapat memberi layanan jasa yang lebih baik bagi para pengunjung khususnya wisatawan mancanegara. Disisi lain, partisipasi dalam kegiatan ini pula memberikan gambaran perlunya penanganan serius atau pemberian pelatihan yang lebih mendalam dan praktis guna kepentingan peningkatan daya tarik lokasi wisata Religi sekaligus peningkatan pendapatan bagi para pelaku usaha. Tak juga dapat disangkal kondisi ini mencerminkan signifikansi Bahasa Inggris dalam kegiatan ekonomi masyarakat bahkan lebih jauh kontribusi penguasaan bahasa dari para pelaku usaha wisata dalam peningkatan pemasukan pendapatan asli daerah.

\section{KESIMPULAN DAN SARAN}

Adanya kegiatan pengabdian berupa pelatihan yang menyajikan pengenalan akan perbendaharaan kata Bahasa Inggris yang terkait Pariwisata disertai dengan pemberian materi seputar cara menyapa dan memandu wisatawan asing bagi para pelaku usaha wisata di Bukit kasih kanonang menghasilkan beberapa hal sebagai berikut:

1. Adanya tanggapan yang baik dari para pelaku usaha wisata dibuktikan dengan kehadiran dan partisipasi dalam kegiatan pelatihan

2. Terbentuknya pengenalan akan katakata Bahasa Inggris yang dapat digunakan dalam kegiatan usaha wisata secara umum dan di Bukit Kasih Kanonang secara khusus.

3. Munculnya minat untuk lebih melatih diri atau mengikuti pelatihan terkait cara menyapa dan memandu pengunjung khususnya wisatawan asing sebagai upaya untuk meningkatkan pendapatan.

4. Bertambahnya wawasan kebahasaan khususnya penggunaan bahasa Inggris untuk tujuan peningkatan kualitas layanan bagi wisatawan asing yang 
berdampak pada peningkatan potensi arus dan kunjungan wisata ke kabupaten Minahasa dan khususnya Bukit Kasih Kanonang.

5. Lahirnya rekomendasi untuk adanya pelatihan lanjutan yang lebih mendalam seputar ungkapan-ungkapan yang dipakai untuk jasa wisata dalam rangka memperkuat upaya peningkatan kunjungan wisata sekaligus peningkatan pendapatan.

\section{KEPUSTAKAAN}

Anthopoulou, T. (2000). Agrotourism and the rural environment: constraints and opportunities in the mediterranean less-favoured areas. In Briassoulis, H. \& van der Straaten, J., (eds.) Tourism and the environment: Regional, economic, cultural and policy issues (pp. 357-372). Boston, MA: Kluwer Academic Publishers.

Bhatia, V. K. (1993). Analyzing genre. Language use in professional settings.London: Longman.

Brandl, K. (2005). Are you ready to "Moodle"? Language Learning \& Technology, 9 (2), 16-23.

.Busby, G., \& Rendle, S. (2000). The transition from tourism on farms to farm tourism. Tourism Management, $21,635-642$

Donald dan Douglas, 1996. Kiat Memasarkan Produk Anda, Pedoman Perencanaan Untuk Perusahaan Kecil. Arcan.Jakarta.

Dudley-Evans, T., \& St John, M. J. (1998). Developments in ESP. A multidisciplinary approach. Cambridge: Cambridge University Press
Ellis, M., \& Johnson, C. (1994). Teaching Business English. London: Oxford University Press

Fridgen, J. (1991). Dimensions of tourism. East Lansing, MI: American Hotel and Motel Association Educational Institute.

Hutchinson, t., \& waters, a. (1987). English for Specific Purposes. A learningcentred approach. Cambridge: Cambridge University Press.

Kuncoro,M. 1997. Ekonomi Industri, Teori Kebijakan dan Studi Empiris di Inonesia. Widya Sarana Informatika. Yogyakarta.

Maskun, S. 1993. Pembangunan Masyarakat Desa Asas, Kebijaksanaan dan Manajemen. Media Widya Mandala. Yogyakarta.

Marbun,B.N. 1986. Kekuatan dan Kelemahan Perusahaan Kecil. Pustaka Binaman Pressindo. Jakarta.

Perry, M. 2000. Mengembangkan Usaha Kecil Dengan Memanfaatkan Berbagai Bentuk Jaringan Kerja Ekonomi. PT raja Grafindo Persada. Jakarta

Pizam, A. and Calantone, R. (1987) Beyond psychographics - values as determinants of tourist behavior. International Journal of Hospitality Management 6(3): 177-181. 